\title{
Dissipation of Bromide and Metribuzin Affected by Tillage and Crop Residue Management in Subarctic Alaska
}

\author{
BRENTON S. SHARRATT ${ }^{1}$ and CHARLES W. KNIGHT ${ }^{2}$
}

(Received 14 May 2004; accepted in revised form 26 January 2005)

\begin{abstract}
Prudent use of agricultural fertilizers and herbicides is paramount for sustaining or improving surface and ground water quality in Subarctic regions, but little information is available that documents the loss of chemicals from agricultural lands in the Subarctic. This study aimed to ascertain more clearly how time of application and land management practices affect the loss of bromide and metribuzin in a Subarctic soil. Potassium bromide (KBr), a surrogate for nitrate, and metribuzin, commonly used to control broadleaf weeds, were applied in the autumn of 1996 and the spring of 1997 to a silt loam that had been subjected to conventional tillage (CT), minimum tillage (disk once [DO]), and no tillage (NT) since 1983. Superimposed on the tillage treatments were the removal or retention of barley (Hordeum vulgare L.) stubble and loose straw. Loss of these chemicals was ascertained by sampling the soil profile at the time of heading of barley, before freeze-up of the soil in autumn, and after spring thaw until September 1998. Tillage and residue treatments did not influence the recovery of autumn-applied or spring-applied Br. However, recovery of $\mathrm{Br}$ diminished with time: about $30 \%$ of the $\mathrm{Br}$ applied in autumn and $45 \%$ of that applied in spring remained in the soil profile by September 1998. Tillage, but not residue, treatments influenced the recovery of metribuzin. Recovery of metribuzin at the termination of this study was $6 \%$ or more in NT soil and $2 \%$ or less in CT and DO soil; greater recovery in NT soil was presumably a result of slower degradation in NT than in CT and DO. This study suggests that bromide (and thus nitrate) and metribuzin are more prone to leaching when applied in autumn and that tillage practices affect retention of metribuzin, but not nitrate, in the soil of Subarctic Alaska.
\end{abstract}

Key words: herbicide, retention, leaching, solute, nitrate

RÉSUMÉ. Une utilisation prudente des engrais et des herbicides est cruciale au maintien ou à l'amélioration de la qualité de l'eau de surface et de l'eau souterraine dans les régions subarctiques, mais il existe peu de documentation sur la déperdition des produits chimiques dans le sol des terres agricoles du Subarctique. Cette étude vise à établir avec plus de précision la façon dont le moment de l'application et les pratiques de gestion des terres affectent la déperdition du bromure et de la métribuzine dans un sol subarctique. Le bromure de potassium (KBr), un substitut du nitrate, et la métribuzine, couramment utilisée pour lutter contre les dicotylédones, ont été appliqués en automne 1996 et au printemps 1997 sur un loam limoneux qui avait subi un travail du sol classique (TC), un travail minimum (un seul passage du cultivateur à disque [TM]) et aucun travail (AT) depuis 1983. On a ajouté au travail du sol le déchaumage de l'orge (Hordeum vulgare L.) ou le maintien du chaume et de la paille. On a vérifié la déperdition de ces produits chimiques jusqu'en septembre 1998 en analysant le profil pédologique au moment de l'épiaison de l'orge, avant que le sol gèle à l'automne et après le dégel printanier. Le travail du sol et le traitement des résidus n'ont pas influencé la récupération du $\mathrm{Br}$ appliqué en automne ou au printemps. La récupération du Br a cependant diminué avec le temps: en septembre 1998, environ $30 \%$ du Br appliqué à l'automne et $45 \%$ de celui appliqué au printemps persistaient dans le profil pédologique. Le travail du sol, mais pas le traitement des résidus, influençait la récupération de la métribuzine. À la fin de l'étude, la récupération de la métribuzine était de $6 \%$ ou plus dans le sol AT, et de $2 \%$ ou moins dans les sols TC et TM; une récupération plus importante dans le sol AT résultait probablement d'une dégradation plus lente dans le AT que dans le TC et le TM. Cette étude suggère que le bromure (et, par conséquent, le nitrate) et la métribuzine sont plus sujets au lessivage quand ils sont appliqués en automne, et que les pratiques de travail du sol affectent la rétention de la métribuzine, mais pas celle du nitrate, dans le sol de l'Alaska subarctique.

Mots clés: herbicide, rétention, lessivage, soluté, nitrate

Traduit pour la revue Arctic par Nésida Loyer.

\section{INTRODUCTION}

Prudent use of agricultural chemicals is paramount for sustaining or improving the quality of surface and ground water in rural communities. Indeed, chemical compounds from fertilizer and herbicide applications have been found in surface and ground water in many agricultural regions of the world (Wauchope, 1978; Hagebro et al., 1983; Goolsby and Battaglin, 1995; Guzzella et al., 1996). Technologies such as soil testing and precision agriculture

\footnotetext{
${ }^{1}$ USDA Agricultural Research Service, 213 LJ Smith Hall, WSU, Pullman, Washington 99164, U.S.A.; sharratt@ wsu.edu

2 Alaska Department of Natural Resources, 3700 Airport Way, Fairbanks, Alaska 99707, U.S.A.

(C) The Arctic Institute of North America
} 
allow producers to regulate chemical applications according to the potential needs of the crop or the variability of soils within a landscape. Uncertainties in weather, however, can result in loss of chemicals from the landscape despite the best management practices. For example, precipitation has resulted in the loss of chemicals from the soil via leaching, runoff, or both, even though the chemicals were placed in a band near the seed (Bowman et al., 1994) or applied after crop emergence (Buttle and Harris, 1991).

The climate and land resources of the Subarctic region of the United States, which lies from about $50^{\circ}$ to $70^{\circ} \mathrm{N}$ latitude, pose challenges to crop production. The severity of the climate, for example, restricts crop diversity and yield (Siddoway et al., 1984). In addition, most soils in this region are poorly suited for agriculture, partly because they are shallower and less fertile than other soils around the world (Visher, 1955). Crop production is also challenged by the keen interest in preserving the pristine environment of the Subarctic. Indeed, in a region where agricultural fields adjoin pristine surface waters, environmental stewardship requires judicious use of agricultural chemicals (Boyer, 1985).

Little information is available that documents the fate of chemicals on agricultural lands in the Subarctic. In interior Alaska, Knight and Sparrow (1993) found that fertilizer $\mathrm{N}$ is vulnerable to movement within a soil that is subjected to conventional tillage. Leaching of $\mathrm{N}$, however, was negligible as $\mathrm{NO}_{3}$ and $\mathrm{NH}_{4}$ were not detected below a depth of $0.45 \mathrm{~m}$ in the soil profile over the course of three growing seasons. Conn and Cameron (1988) suggested that degradation is the primary cause of loss of metribuzin, accounting for $70 \%$ of loss over the course of a growing season in interior Alaska. Their study, however, quantified metribuzin near the surface of cultivated or fallow soil and did not consider movement that may have occurred below a $0.15 \mathrm{~m}$ depth. In Siberia, Gamzikov et al. (1985) reported that $24 \%$ of fertilizer $\mathrm{N}$ was used by the crop during the growing season, whereas $51 \%$ remained in the soil at harvest. They also found that $25 \%$ of the applied $\mathrm{N}$ was lost from the soil as a result of either denitrification or leaching during the growing season. Barsukov (1997) reported a loss of fertilizer $\mathrm{N}$ other than that taken up by cereal crops grown in western Siberia, but found no evidence of leaching of N. Precipitation is not generally sufficient to cause leaching during the early growing season (before early July) in Siberia. He suggested, however, that leaching of $\mathrm{N}$ might occur during spring as a result of snowmelt infiltration.

Virtually no information exists on the influence of time of application or land-management practices on the loss of fertilizers and herbicides from Subarctic soils. Observations in more temperate regions suggest that no tillage can result in more rapid movement of water and chemicals through the soil profile as compared with conventional tillage (Shipitalo and Edwards, 1993; Wu et al., 1995). In addition, herbicides applied in autumn may be less susceptible to runoff and leaching than those applied in spring in areas where intense rains are less likely to occur in autumn than in spring (Sharratt et al., 2003). This study aimed to ascertain more precisely the loss of bromide, a surrogate for nitrate, and metribuzin, a common herbicide used to control weeds, in Subarctic soils subjected to spring and autumn chemical applications and to various tillage and crop residue practices.

\section{METHODS AND MATERIALS}

This study was conducted at the University of Alaska Agricultural and Forestry Experiment Station, located near Delta Junction, Alaska $\left(63^{\circ} 55^{\prime} \mathrm{N}, 145^{\circ} 20^{\prime} \mathrm{W}\right)$. Delta Junction is characterized by a continental climate, with mean annual air temperature of $-2.5^{\circ} \mathrm{C}$ and annual precipitation of $300 \mathrm{~mm}$. Atmospheric conditions are cold and dry during winter, but warm and dry during the growing season (about 90 frost-free days). The experimental site was cleared of native spruce vegetation in 1978 and has been cropped to barley each year since 1982. The site is nearly level $(0.5 \%$ slope $)$, and the soil is classified as a Volkmar silt loam (coarse-silty over sandy or sandyskeletal, mixed, nonacid Aeric Cryaquepts). The topsoil has a bulk density of $700 \mathrm{~kg} \mathrm{~m}^{-3}$ and is composed of $45 \%$ sand and 7\% clay (Sharratt, 1996). Outwash sand and gravel generally occur below a depth of $0.5 \mathrm{~m}$. The soil has a pH of 5.1 and organic carbon content of 5.8\% (Sparrow and Cochran, 1988).

\section{Tillage-Residue Treatments}

Experimental plots were established in 1983 to assess barley growth and production in the Subarctic under a range of tillage and residue management practices. The experimental design, replicated three times, was split plot with tillage as the main treatment and residue management as the secondary treatment. Tillage treatments were 1) Conventional tillage (CT) - plots were disked to a depth of $10 \mathrm{~cm}$ after autumn harvest and again in the spring prior to sowing, 2) Disk once (DO) - plots were disked to a depth of $10 \mathrm{~cm}$ in the spring only, and 3) No tillage (NT). Residue treatments were 1) Stubble/straw (SS) - stubble and loose straw remained on the soil surface after combine harvest, and 2) No stubble/straw (NSS) - stubble and loose straw were removed from the soil surface after harvest.

\section{Chemical Applications}

Loss of $\mathrm{Br}$ and metribuzin from tillage and residue treatments was ascertained over a two-year period from 1996 to 1998 . Bromide was used in this study because it is a surrogate for nitrate (Smith and Davis, 1974), a conservative tracer (experiencing neither gain nor loss during transport), nonreactive with the mineral and organic fractions of the soil, low in concentration in the environment, and inexpensive to apply and quantify (Davis et al., 1980). 
Metribuzin was chosen for this experiment as a potential contaminant because of its low sorption coefficient (52) and high water solubility (1220 $\mathrm{mg} \mathrm{L}^{-1}$ ) compared to other herbicides (U.S. Department of Agriculture, 2004). Metribuzin is commonly used to control broadleaf weeds, but it had not been previously used on the experimental plots.

Potassium bromide (KBr) and metribuzin were applied to tillage-residue plots in the autumn of 1996 (autumn application) and spring of 1997 (spring application). Straw treatments were established after autumn harvest, and tillage treatments were then performed before application of the chemicals. Chemicals were applied to a $4 \mathrm{~m}^{2}$ area within each plot. $\mathrm{KBr}$ (one part mixed with 10 parts dry sand) was broadcast on the soil surface at a rate of $1000 \mathrm{~kg}$ $\mathrm{KBr} \mathrm{ha}{ }^{-1}$ and metribuzin was sprayed on the soil surface at the recommended rate of $600 \mathrm{~kg} \mathrm{ha}^{-1}$ on 4 September 1996. Soil samples taken within days of application (see below) indicated an equivalent application rate of about $600 \mathrm{~kg} \mathrm{Br}$ $\mathrm{ha}^{-1}$ (standard error of $60 \mathrm{~kg} \mathrm{ha}^{-1}$ ) and about $0.5 \mathrm{~kg}$ metribuzin $\mathrm{ha}^{-1}$ (standard error of $0.05 \mathrm{~kg} \mathrm{ha}^{-1}$ ). Application of chemicals to the soil surface of the DO-SS and NT-SS treatments necessitated removing (by raking) only the loose straw (not stubble) from the treated area. Loose straw was then broadcast over the treated area immediately after the chemical application.

Spring application of $\mathrm{KBr}$ was completed after spring tillage, and both occurred on 7 May 1997. Metribuzin was applied on 3 June 1997 after the emergence of barley. Application of chemicals to the soil surface of the NT-SS treatment necessitated removing loose straw from the treated area. Loose straw was broadcast over the treated area after application. No further chemical $(\mathrm{KBr}$ and metribuzin) applications were made. Loss of $\mathrm{Br}$ and metribuzin in the soil profile was measured by soil sampling over the two subsequent (1997 and 1998) growing seasons. During each growing season, the area treated with chemicals was subjected to the tillage and residue management practices designated for that experimental plot. Barley was cut (about $0.2 \mathrm{~m}$ above the soil surface) and removed from the treated area (to minimize $\mathrm{Br}$ additions to the soil surface) before harvesting of plots with a combine. Farm implements were pulled slowly through the treated area to minimize the lateral movement of soil near the surface. Autumn tillage-residue treatments were performed after harvest on 16 September 1997, and spring tillage was performed on 14 May 1998. Barley was planted on 9 May 1997 and on 14 May 1998.

\section{Soil Sampling}

In the autumn of 1996 , soil samples were collected before and six days after application of $\mathrm{KBr}$ and metribuzin (on 4 and 10 September). In the spring of 1997, soil samples were collected on 7 May (before the spring application), 8 May (one day after spring application of $\mathrm{KBr}$ ), and 8 June (five days after spring application of metribuzin).
In both autumn and spring, precipitation did not occur from the time of application to the day of initial soil sampling. Soil samples were also collected on 1 July 1997 , 25 September 1997, 5 May 1998, 9 July 1998, and 17 September 1998. These dates correspond to heading of barley in 1997, before freeze-up of the soil in autumn 1997, after thaw of the soil profile in spring 1998, heading of barley in 1998, and prior to freeze-up of the soil in autumn 1998. The soil likely remained frozen for the duration of winter beginning 3 October 1996 (23 days after soil sampling), 5 October 1997 (10 days after soil sampling), and 1 October 1998 (14 days after soil sampling), as mean daily air temperatures recorded at the Big Delta FAA weather observatory were persistently below $0^{\circ} \mathrm{C}$ after these dates. Soil core samples were collected using a hydraulic soil probe equipped with a $53 \mathrm{~mm}$ diameter stainless steel sampling cylinder. The soil profile was sampled to a depth of $1 \mathrm{~m}$ except on those occasions (over $50 \%$ of the samples) when gravel prevented further insertion of the sampling tube into the profile. Two soil core samples were extracted from each plot area on each sample date. After extraction of each sample, the void was filled with untreated soil and marked for future reference. Core samples were sectioned into $0.1 \mathrm{~m}$ increments and consolidated by depth interval. The samples were kept frozen until preparations were made for chemical analysis.

\section{Chemical Analysis}

Frozen soil samples were thawed, air-dried, and ground to pass through a $2 \mathrm{~mm}$ sieve. All samples were analyzed within 90 days after thawing. On the basis of the relationship between the rate of degradation and the moisture and temperature conditions of the samples, we anticipated less than 5\% loss of metribuzin from the soil samples over 90 days (Nicholls et al., 1982). Soil samples were analyzed for metribuzin according to Basta and Olness (1992). Samples were prepared for extraction by adding $25 \mathrm{~mL}$ of a methanol:de-ionized water solution $(8: 2 \mathrm{vol} / \mathrm{vol})$ to $10 \mathrm{~g}$ of air-dried soil. This slurry was shaken and then equilibrated for three hours. The liquid was decanted through a glass filter, heated to evaporate the methanol, and then vacuum filtered through solid phase extraction (SPE) columns at $2 \mathrm{~mL} \mathrm{~min}{ }^{-1}$. Metribuzin was eluted from SPE columns with $2 \mathrm{~mL}$ of methanol and quantified by gas chromatography with a minimum detectible concentration of $10 \mu \mathrm{g} \mathrm{kg}^{-1}$. The extraction efficiency of this procedure on spiked soil samples was $94 \%$.

Soil samples were analyzed for $\mathrm{Br}$ using a colorimetric procedure similar to Olson and Cassel (1999). Soil samples were prepared for Br extraction by adding $25 \mathrm{~mL} 0.1 \mathrm{M}$ (moles) $\mathrm{NaNO}_{3}$ to $10 \mathrm{~g}$ of air-dried soil and shaking for $1 \mathrm{~h}$. The slurry was filtered and the filtrate was analyzed for Br using an Alpkem autoanalyzer that was calibrated using standard $\mathrm{Br}$ solutions. Extraction efficiencies using this procedure on spiked soil samples were about $97 \%$. The detection limit was $2 \mu \mathrm{g} \mathrm{g}^{-1}$. 
In this paper, recovery of $\mathrm{Br}$ and metribuzin is reported in relation to the quantity recovered immediately after application. Recovery within the soil profile on each sample date was determined from the cumulative amounts of $\mathrm{Br}$ and metribuzin obtained from all sections of a soil core sample. Mass of $\mathrm{Br}$ and metribuzin contained in each section was determined using surface bulk density profiles of the tillage treatments as reported by Sharratt (1996) and subsurface density profiles at the experimental site as reported by Sharratt (1990).

\section{Statistical Analysis}

The experimental data were analyzed as a split plot design using Analysis of Variance (ANOVA). Least significant difference (LSD) was used to separate main treatment effects and interactions when significant F-values $(p \leq 0.05)$ were determined by the analysis. In addition, differences in recovery as a function of time were examined using ANOVA, with date of sampling as the subsubplot factor in a split-split plot experimental design.

\section{RESULTS AND DISCUSSION}

Atmospheric conditions were warmer and wetter than normal for the duration of this study (September 1996 through September 1998). Air temperatures were $1.1^{\circ} \mathrm{C}$ above the 30 -year average of $-2.0^{\circ} \mathrm{C}$, while precipitation was $40 \mathrm{~mm}$ above the 30 -year average of $615 \mathrm{~mm}$ over this 25 -month period. Particularly noteworthy was the warm winter (October through March) of 1997-98 (Fig. 1). Monthly air temperatures were $0.1^{\circ}$ to $6.0^{\circ} \mathrm{C}$ above average except in October 1997, when air temperatures were $5.0^{\circ} \mathrm{C}$ below the 30 -year average. Also exceptional were the dry conditions that prevailed during the first half of the growing season (May and June) and wet conditions that occurred during the latter half of the growing season (July and August) in 1997 and 1998 (Fig. 1).

\section{Bromide}

Approximately $30 \%$ of the $\mathrm{Br}$ applied in September 1996 remained in the soil profile two years later (Fig. 2). In comparison, about $45 \%$ of the $\mathrm{Br}$ applied in May 1997 remained in the soil by September 1998. Thus, from 55\% to $70 \%$ of $\mathrm{Br}$ applied to the soil was lost as a consequence of leaching, plant uptake, or runoff. Loss of $\mathrm{Br}$ due to runoff was assumed negligible in this study because the experimental site was nearly level, daily precipitation events rarely exceeded $20 \mathrm{~mm}$ (except for the $46 \mathrm{~mm}$ event on 17 July 1998), and the soil was highly permeable (Sharratt, 1990, 1996).

Neither tillage nor residue treatments influenced $\mathrm{Br}$ recovery in this study (Table 1). These findings agree with those of Bicki and Guo (1991), in which tillage did not influence $\mathrm{Br}$ recovery in an Agriudoll in Illinois. As indicated by Bicki and Guo (1991), dissimilarities in porosity caused by tillage have little influence on solute movement (and therefore, solute loss) under conditions of limited precipitation and restricted soil water flow. Soil porosity and water retention characteristics can also be altered by tillage in the Subarctic (Sharratt, 1996), but any apparent changes in these soil properties had no effect on Br recovery.

Date of sampling did influence $\mathrm{Br}$ recovery from the soil profile (Table 1), with recovery diminishing with time after application (Fig. 2). Loss of both autumn-applied and springapplied $\mathrm{Br}$ occurred between the autumn and spring sample dates, presumably either before soil freeze-up in the autumn or after initiation of snowmelt and soil thaw in the spring. Loss of autumn-applied $\mathrm{Br}$ between autumn and spring was more apparent in the first year of this study than in the second year. About $20 \%$ of the autumn-applied $\mathrm{Br}$ (or $120 \mathrm{~kg} \mathrm{ha}^{-1}$ ) was lost between autumn 1996 and spring 1997 while 5\% of the applied $\mathrm{Br}$ (or $30 \mathrm{~kg} \mathrm{ha}^{-1}$ ) was lost between autumn 1997 and spring 1998. Loss of autumn-applied Br between autumn 1996 and spring 1997 may have been accentuated by heavy precipitation during this period, $70 \%(50 \mathrm{~mm})$ more precipitation than was received during the subsequent autumn-tospring sample period. Extreme single-day precipitation events did not accentuate loss the first year, as the greatest single-day event equaled $12 \mathrm{~mm}$ during both autumn-to-spring periods. These single-day events, which occurred on 7 November 1996 and 9 October 1997, likely had no immediate impact on chemical movement within the soil profile, since precipitation was in the form of snow and either dissipated via sublimation/wind or persisted until spring melt. About $5 \%$ of the spring-applied $\mathrm{Br}$ (or $30 \mathrm{~kg} \mathrm{ha}^{-1}$ ) was lost from the soil profile between autumn 1997 and spring 1998.

Loss of autumn-applied and spring-applied Br occurred during the early portion of the growing season. From early May to early July, loss of autumn-applied $\mathrm{Br}$ was equivalent to $145 \mathrm{~kg} \mathrm{ha}^{-1}$ (25\% of that applied) in 1997 and $105 \mathrm{~kg} \mathrm{ha}^{-1}$ (about $20 \%$ of that applied) in 1998. Likewise, loss of spring-applied $\mathrm{Br}$ was equivalent to $170 \mathrm{~kg} \mathrm{ha}^{-1}$ (about $30 \%$ of that applied) in 1997 and to $115 \mathrm{~kg} \mathrm{ha}^{-1}(20 \%$ of that applied) in 1998. This loss appeared to result from plant uptake rather than leaching. Indeed, plant uptake of $100 \mathrm{~kg} \mathrm{Br} \mathrm{ha}{ }^{-1}$ or more is not uncommon for barley (Pearson et al., 1996) or sorghum (Chao, 1966). In addition, leaching is minimal at this time of year in interior Alaska. Knight and Sparrow (1993) found negligible leaching of fertilizer N in a barley cropping system over the course of three growing seasons. Leaching may also be minimal because evapotranspiration exceeds precipitation between May and July, so soil water reserves are rapidly depleted (Braley, 1980; Sharratt, 1998). Precipitation between early May and early July in subsequent years equaled 63 and $51 \mathrm{~mm}$, and the greatest single-day event approached only $18 \mathrm{~mm}$ in 1997 (8 June) and $9 \mathrm{~mm}$ in 1998 (6 July).

Loss of autumn-applied and spring-applied $\mathrm{Br}$ from the soil profile also occurred late in the growing season, although loss was not as apparent as during the early 


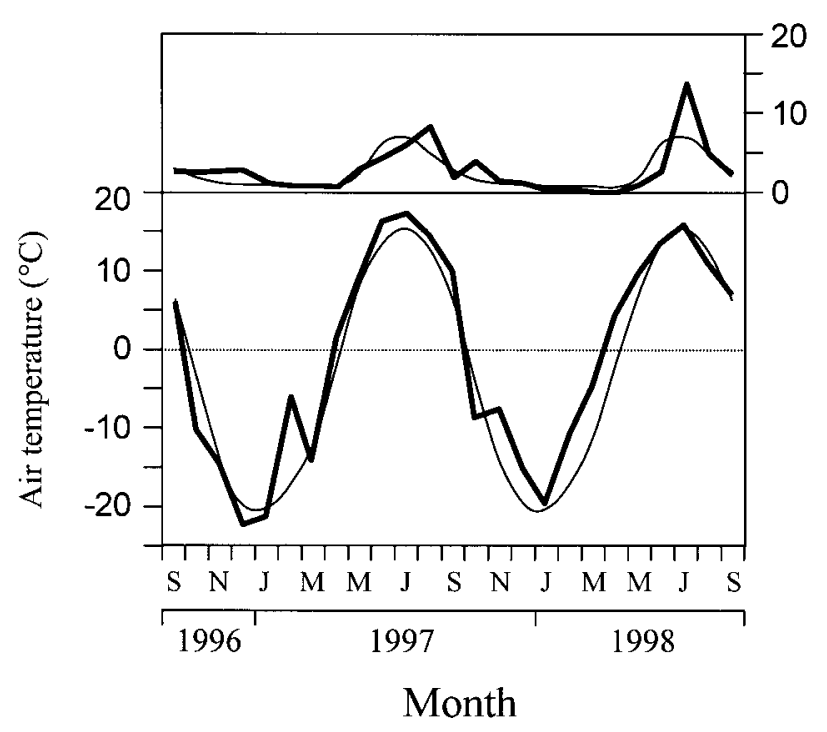

FIG. 1. Monthly observed (bold lines) and 30-year normal air temperature (bottom) and precipitation (top) at the Big Delta FAA weather observatory during the 25-month experimental period.

growing season (Fig. 2). In fact, between the early July and late September sampling dates, loss of autumn-applied and spring-applied $\mathrm{Br}$ was typically less than $5 \mathrm{~kg} \mathrm{ha}^{-1}$ (less than $1 \%$ of that applied). This relatively small loss may occur because barley attains physiological maturity by late July and thereafter requires little water and nutrients to sustain maturation processes. Loss of autumn-applied $\mathrm{Br}$, however, was not observed during the latter portion of the 1997 growing season. In fact, an increase in $\mathrm{Br}\left(15 \mathrm{~kg} \mathrm{ha}^{-1}\right)$ was observed between the July and September 1997 sample dates. Although this increase in Br may be an aberration, enhanced recovery may be a consequence of leaching of $\mathrm{Br}$ from vegetation after physiological maturity. Loss of spring-applied $\mathrm{Br}$ in the latter portion of the growing season appeared consistent between 1997 and 1998 despite differences in precipitation. Precipitation was $10 \%$ $(20 \mathrm{~mm})$ greater between the July and September sampling dates in 1998 than in 1997, and the extreme single-day event approached $46 \mathrm{~mm}$ in 1998 (17 July) and only $17 \mathrm{~mm}$ in 1997 (16 August).

Br was not detected below a depth of $50 \mathrm{~cm}$ on any sampling date in this study (Fig. 3). This depth corresponds closely to the maximum depth of rooting of barley in interior Alaska (Sharratt and Cochran, 1992) and to the depth of outwash sand and gravel. Failure to detect $\mathrm{Br}$ below $50 \mathrm{~cm}$ may then be due to depletion of $\mathrm{Br}$ as a result of plant uptake or rapid leaching through sand and gravel. Bromide applied in September 1996 was detected at this depth by May 1997 (data not shown), indicating that leaching had occurred within the soil profile. Movement of Br likely occurred after the initiation of spring thaw, since less than $10 \mathrm{~mm}$ of precipitation fell between the day of application (4 September) and freeze-up of the soil (3 October) in the autumn. Bromide applied in May 1997 was detected at the $50 \mathrm{~cm}$ depth in all tillage and residue treatments by September 1997.

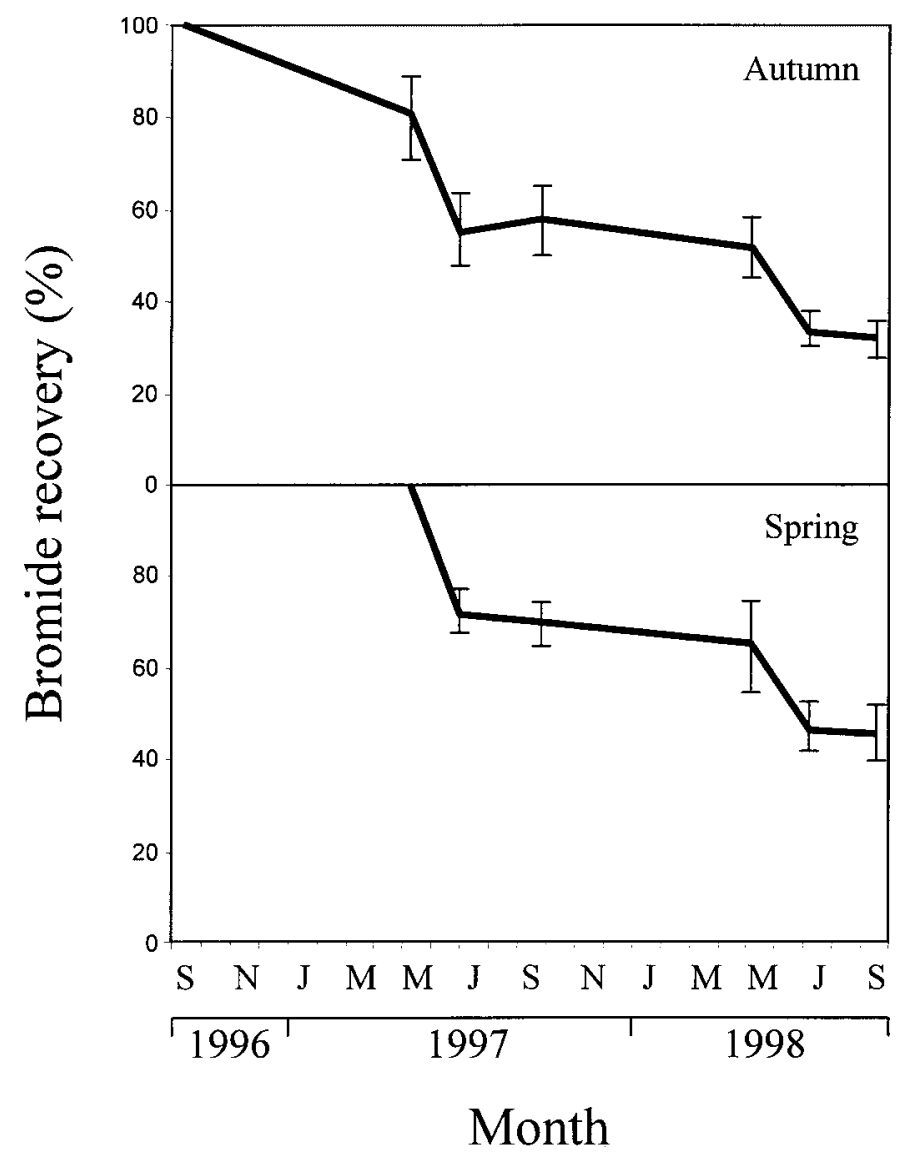

FIG. 2. Percent mass recovery of autumn-applied and spring-applied bromide from the time of application in September 1996 and May 1997, respectively, to September 1998. Bars indicate the range of recovery across all tillage and residue management treatments.

\section{Metribuzin}

Movement of metribuzin was not detected within the soil profile. In fact, metribuzin was not detected below a depth of $10 \mathrm{~cm}$ at any time during this study (data not shown). Other reports also suggest that the mobility of metribuzin within soils is limited. Sharom and Stephenson (1976), for example, found limited movement of metribuzin (generally less than $10 \mathrm{~cm}$ ) after wetting $20 \mathrm{~cm}$ long thin sections of organic soils and mineral soils that ranged in texture from sand to clay. In addition, Nicholls et al. (1982) observed little movement (less than $10 \mathrm{~cm}$ ) of metribuzin applied at the surface to sandy loam that was maintained fallow over an entire growing season in England. Little or no movement of metribuzin within the soil profile may occur because this chemical is tightly bound to soils with high clay or organic matter content (Sharom and Stephenson, 1976; Peter and Weber, 1985) or low pH (Ladlie et al., 1976). Although the clay content of the soil in this study is $7 \%$, the soil is rich in organic material $(5.8 \%$ organic carbon content).

Tillage intensity appeared to accentuate the loss of metribuzin. Differences in loss among tillage treatments were first evident at the end of the 1997 growing season. At the end of this study, less metribuzin remained in the 
TABLE 1. Analysis of Variance for the recovery of autumn-applied and spring-applied bromide at Delta Junction, Alaska, as influenced by tillage, residue management, and date of sampling.

\begin{tabular}{|c|c|c|c|c|}
\hline Application $^{1}$ & Source & df & F-value & P-value \\
\hline \multirow[t]{9}{*}{ Autumn } & Replication & 2 & & \\
\hline & Tillage & 2 & 0.01 & 0.99 \\
\hline & Residue & 1 & 3.20 & 0.08 \\
\hline & Tillage $\times$ Residue & 2 & 1.00 & 0.37 \\
\hline & Date & 5 & 17.55 & 0.00 \\
\hline & Tillage $\times$ Date & 10 & 0.11 & 0.99 \\
\hline & Residue $\times$ Date & 5 & 0.02 & 0.99 \\
\hline & Tillage $\times$ Residue $\times$ Date & 10 & 0.27 & 0.98 \\
\hline & Error & 66 & & \\
\hline \multirow[t]{9}{*}{ Spring } & Replication & 2 & & \\
\hline & Tillage & 2 & 0.39 & 0.70 \\
\hline & Residue & 1 & 1.23 & 0.27 \\
\hline & Tillage $\times$ Residue & 2 & 0.77 & 0.47 \\
\hline & Date & 4 & 6.98 & 0.00 \\
\hline & Tillage $\times$ Date & 8 & 0.29 & 0.97 \\
\hline & Residue $\times$ Date & 4 & 0.15 & 0.96 \\
\hline & Tillage $\times$ Residue $\times$ Date & 8 & 0.11 & 0.99 \\
\hline & Error & 54 & & \\
\hline
\end{tabular}

${ }^{1}$ Autumn application on 4 September 1996; spring application on 7 May 1997.

TABLE 2. Recovery of autumn-applied and spring-applied metribuzin (relative to the quantity recovered shortly after application) from a soil at Delta Junction, Alaska, subjected to various tillage practices.

\begin{tabular}{|c|c|c|c|c|c|c|c|}
\hline \multirow[t]{3}{*}{ Application $^{1}$} & \multirow[t]{3}{*}{ Treatment $^{2}$} & \multicolumn{6}{|c|}{ Recovery (\%) } \\
\hline & & \multicolumn{3}{|c|}{1997} & \multicolumn{3}{|c|}{1998} \\
\hline & & $05 / 08$ & $07 / 01$ & $09 / 25$ & $05 / 05$ & $07 / 09$ & $09 / 17$ \\
\hline \multirow[t]{4}{*}{ Autumn } & CT & 74 & 42 & 5 & 3 & 0 & 0 \\
\hline & $\mathrm{DO}$ & 74 & 42 & 9 & 8 & 2 & 2 \\
\hline & NT & 71 & 43 & 12 & 7 & 6 & 6 \\
\hline & LSD $^{3}$ & NS & NS & 6 & NS & 2 & 2 \\
\hline \multirow[t]{4}{*}{ Spring } & $\mathrm{CT}$ & & 53 & 20 & 6 & 0 & 0 \\
\hline & DO & & 58 & 20 & 11 & 5 & 1 \\
\hline & NT & & 57 & 30 & 18 & 9 & 8 \\
\hline & LSD & & NS & 9 & 10 & 4 & 2 \\
\hline
\end{tabular}

${ }^{1}$ Autumn application on 4 September 1996; spring application on 3 June 1997.

${ }^{2} \mathrm{CT}$ is conventional tillage, DO is disk once, and NT is no tillage.

${ }^{3}$ Least Significant Difference at $p \leq 0.05$; NS indicates not significantly different.

soil profile of the CT treatment than in that of the NT treatment (Table 2). Indeed, no metribuzin was detected in the soil profile of the CT treatment while $6 \%$ or more of the applied metribuzin remained in the soil profile of the NT treatment at the end of the 1998 growing season. Loss of metribuzin from the soil profile over the course of this study can result from plant uptake, volatilization, degradation, or both. Volatilization of metribuzin is generally small (Savage, 1980). Differences in recovery of metribuzin likely resulted from differences in degradation among tillage treatments. No tillage delays warming and results in cooler and wetter soils during the growing season in

\section{Bromide fraction}

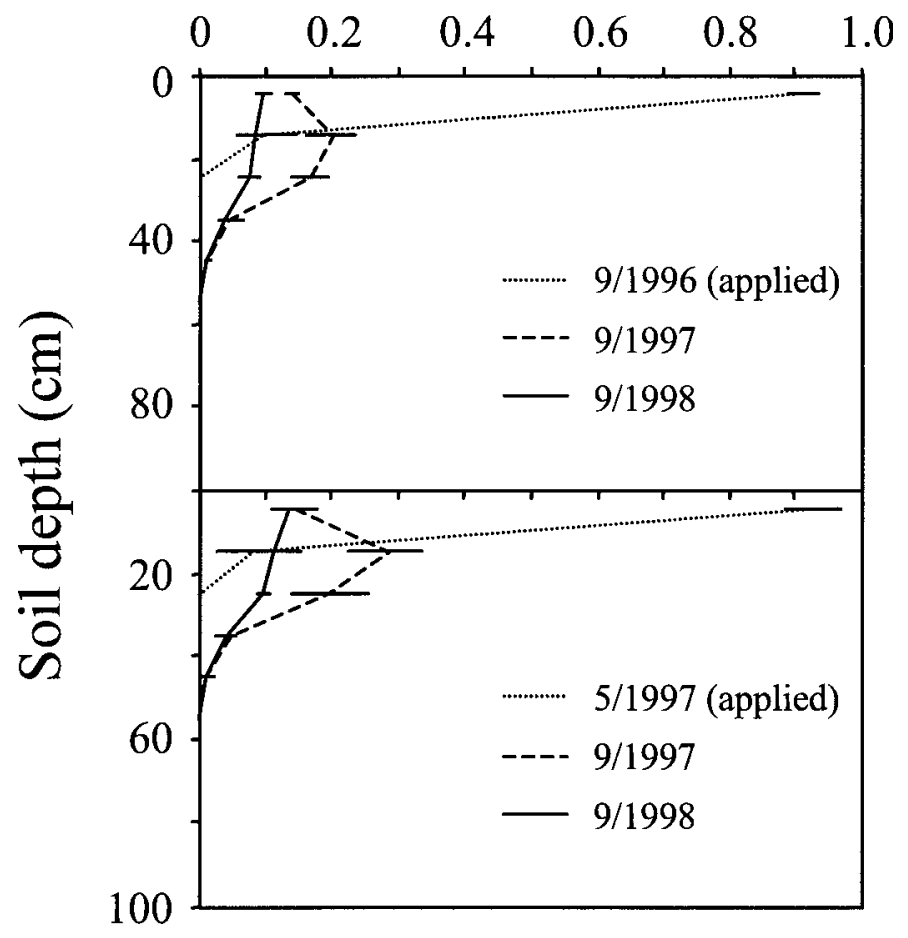

FIG. 3. Fraction of mass recovery of autumn-applied and spring-applied bromide in a silt loam profile immediately after application in September 1996 and May 1997 and then in the autumn of 1997 and 1998. Bars indicate the range of recovery across all tillage and residue treatments.

interior Alaska (Bidlake et al., 1992), conditions which then retard degradation of metribuzin (Walker, 1978). Locke and Harper (1991) also observed slower degradation of metribuzin in soils subjected to no tillage; they attributed this slow degradation to the higher organic carbon content of soils managed using no tillage versus conventional tillage. Similarly, degradation may have been influenced by organic carbon in this study as the soil organic carbon content is greater in the no tillage treatment as compared with other tillage treatments (Zhang and Sparrow, 2004). Residue management had no influence on loss of metribuzin.

Recovery of metribuzin diminished with time (Table 2). About $25 \%$ of that chemical applied in the autumn was lost from the soil by the following spring. This loss is presumed to be the result of degradation, and not leaching, either before freeze-up of the soil in autumn 1996 or after initiation of thaw in spring 1997. Leaching was assumed negligible because precipitation in the autumn was mini$\mathrm{mal}$ ( $10 \mathrm{~mm}$ between the day of application and freeze-up) and no metribuzin was detected below a depth of $10 \mathrm{~cm}$. Likewise, from $30 \%$ to $50 \%$ of the residual metribuzin in the soil profile at the end of the 1997 growing season had been lost by spring 1998. This finding contrasts with that of a previous cropping systems experiment by Conn and Cameron (1988), who found no degradation of metribuzin from September to May in a plot that was located near our tillage plots. Loss of metribuzin between autumn and 
spring may have been greater in the present study because springs were warmer or wetter in 1997 and 1998 than in 1983 and 1984, when Conn and Cameron sampled for metribuzin. The half-life of metribuzin (determined by linear interpolation between sample dates, since firstorder kinetics did not fit the data) differed among tillage treatments, but only when the chemical was applied in spring. Fifty percent of spring-applied metribuzin had dissipated 43 days after application to the CT and DO treatments and 49 days after application to the NT treatment. The half-life of autumn-applied metribuzin was about 285 days. A half-life of 20 to 210 days has been reported for metribuzin incubated under a range of soil moisture and temperature conditions (Walker, 1978). In contrast to our results, Weed et al. (1995) found no differences in the half-life of metribuzin (32 days) applied to a loam soil in Iowa subjected to four tillage methods. About $80 \%$ of the spring-applied metribuzin and $90 \%$ of that applied in autumn were lost from the soil at the end of the first growing season. This loss of spring-applied metribuzin is comparable to that found by Conn and Cameron (1988) in interior Alaska.

\section{CONCLUSIONS}

Approximately $30 \%$ of the $\mathrm{Br}$ applied in September 1996 and $45 \%$ of the May 1997 application remained in the soil profile by September 1998. Thus, from $55 \%$ to $70 \%$ of $\mathrm{Br}$ applied to the soil had been lost as a result of leaching or plant uptake. Leaching resulted in a loss of 5\% to $20 \%$ of the $\mathrm{Br}$ in the soil profile either before freeze-up of the soil in autumn or during spring thaw. Br was most susceptible to leaching when applied in autumn as opposed to spring. Plant uptake during the growing season was presumed to deplete $20 \%$ to $30 \%$ of $\mathrm{Br}$ from the soil profile. Metribuzin was also susceptible to loss from the soil profile, presumably as a result of degradation rather than leaching. Degradation may have been retarded by tillage practices that suppressed soil warming during the growing season or increased the organic carbon content of soil (e.g., no tillage). This study suggests that although tillage and residue management will not influence the loss of nitrate, tillage will affect herbicide persistence in Aeric Cryaquepts of Subarctic Alaska.

\section{REFERENCES}

BARSUKOV,P.A. 1997. Effects of past fertilizer treatments on the fate of newly added fertilizer nitrogen applied to cereal crops in Siberia. In: Iskandar, I.K., Wright, E.A., Radke, J.K., Sharratt, B.S., Groenevelt, P.H., and Hinzman, L.D., eds. International Symposium on Physics, Chemistry, and Ecology of Seasonally Frozen Soils. Cold Regions Research and Engineering Laboratory Special Report 97-10. Hanover, New Hampshire: CRREL. 320-326.
BASTA, N.T., and OLNESS, A. 1992. Determination of alachlor, atrazine, and metribuzin in soil by resin extraction. Journal of Environmental Quality 21:497-502.

BICKI, T.J., and GUO, L. 1991. Tillage and simulated rainfall intensity effect on Br movement in an Argiudoll. Soil Science Society of America Journal 55:794-799.

BIDLAKE, W.R., CAMPBELL, G.S., PAPENDICK, R.I., and CULLUM, R.F. 1992. Seed-zone temperature and moisture conditions under conventional and no-tillage in Alaska. Soil Science Society of America Journal 56:1904-1910.

BOWMAN, B.T., WALL, G.J., and KING, D.J. 1994. Transport of herbicides and nutrients in surface runoff from corn cropland in southern Ontario. Canadian Journal of Soil Science 74:59-66.

BOYER, R.L. 1985. Soil conservation in Alaska: Past and present. Agroborealis 17:23-30.

BRALEY, W.A. 1980. Estimates of evapotranspiration from barley and rapeseed in interior Alaska. MS thesis, University of Alaska Fairbanks.

BUTTLE, J.M., and HARRIS, B.J. 1991. Hydrological pathways of metolachlor export from an agricultural watershed. Water, Air, and Soil Pollution 60:315-335.

CHAO, T.T. 1966. Effect of nitrogen forms on the adsorption of bromide by sorghum. Agronomy Journal 58:595-596.

CONN, J.S., and CAMERON, J.S. 1988. Persistence and carryover of metribuzin and triallate in subarctic soils. Canadian Journal of Soil Science 68:827-830.

DAVIS, S.N., THOMPSON, G.M., BENTLEY, H.W., and STILES, G. 1980. Ground-water tracers: A short review. Ground Water 18:14-23.

GAMZIKOV, G.P., KOSTRIC, G.I., and EMELIYANOVA, V.N. 1985. Fate and transformation of fertilizer nitrogen (In Russian). Novosibirsk, Russia: Nauka. 160 p.

GOOLSBY, D.A., and BATTAGLIN, W.A. 1995. Occurrence and distribution of pesticides in rivers of the Midwestern United States. In: Leng, M.L., Leovey, E.M.K., and Zubkoff, P.L., eds. Agrochemical environmental fate: State of the art. Boca Raton, Florida: CRC Press Inc. 159-173.

GUZZELlA, I., DePAOLIS, A., BARTONE, C., POZZONI, F., and GIULIANO, G. 1996. Migration of pesticide residues from agricultural soil to groundwater. International Journal of Environmental and Analytical Chemistry 65:261-275.

HAGEBRO, C., BANG, S., and SOMER, E. 1983. Nitrate load/ discharge relationship and nitrate load trends in Danish rivers. Hamburg, Germany: International Association of Hydrological Sciences Publication 141:377-386.

KNIGHT, C.W., and SPARROW, S.D. 1993. Urea nitrogen budget for a subarctic agricultural soil. Soil Science Society of America Journal 57:1138-1144.

LADLIE, J.S., MEGGIT, W.F., and PENNER, D. 1976. Role of pH on metribuzin dissipation in field soils. Weed Science 24: $508-511$.

LOCKE, M.A., and HARPER, S.S. 1991. Metribuzin degradation in soil: II - effects of tillage. Pesticide Science 31:239-247.

NICHOLLS, P.H., WALKER, A., and BAKER, R.J. 1982. Measurement and simulation of the movement and degradation of atrazine and metribuzin in a fallow soil. Pesticide Science 12:484-494. 
OLSON, G.L., and CASSEL, D.K. 1999. Bromide leaching on a Piedmont toposequence. Soil Science Society of America Journal 63:1319-1326.

PEARSON, R.J., INSKEEP, W.P., WRAITH, J.M., COMFORT, S.D., and GABER, H.M. 1996. Observed and simulated solute transport under varying water regimes: I. Bromide and pentafluorobenzoic acid. Journal of Environmental Quality 25:646-653.

PETER, C.J., and WEBER, J.B. 1985. Adsorption, mobility, and efficacy of metribuzin as influenced by soil properties. Weed Science 33:868-873.

SAVAGE, K.E. 1980. Metribuzin persistence on the soil surface. Proceedings of the Southern Weed Science Society 33:288.

SHAROM, M.S., and STEPHENSON, G.R. 1976. Behavior and fate of metribuzin in eight Ontario soils. Weed Science 24: $153-160$.

SHARRATT, B.S. 1990. Water retention, bulk density, particle size, and thermal and hydraulic conductivity of arable soils in interior Alaska. University of Alaska Agricultural and Forestry Experiment Station Bulletin 83. 9 p.

-1996. Tillage and straw management for modifying physical properties of a subarctic soil. Soil \& Tillage Research 38: $239-250$.

- 1998. Barley yield and evapotranspiration governed by tillage practices in interior Alaska. Soil \& Tillage Research 46:225-229.

SHARRATT, B.S., and COCHRAN, V.L. 1992. Skip-row and equidistant-row barley with nitrogen placement: Yield, nitrogen uptake, and root density. Agronomy Journal 85:246-250.

SHARRATT, B.S., SANDER, K., and TIERNEY, D. 2003. Fate of autumn-applied metolachlor in a clay loam in the northern U.S. Corn Belt. Journal of Environmental Science and Health B38: 37-48.

SHIPITALO, M.J., and EDWARDS, W.M. 1993. Seasonal patterns of water and chemical movement in tilled and no-till column lysimeters. Soil Science Society of America Journal 57: 218-223.

SIDDOWAY, F.H., LEWIS, C.E., and CULLUM, R.F. 1984. Conservation-tillage and residue-management systems for interior Alaska. Agroborealis 16:35-40.

SMITH, S.J., and DAVIS, R.J. 1974. Relative movement of bromide and nitrate through soils. Journal of Environmental Quality 3:152-155.

SPARROW, S.D., and COCHRAN, V.L. 1988. Carbon and nitrogen mineralization in subarctic and forest soils. Biology and Fertility of Soils 6:33-38.

U.S. DEPARTMENT OF AGRICULTURE. 2004. The ARS pesticide properties database. Www.ars.usda.gov/Services/ docs.htm?docid=6433. Accessed 7 April 2005.

VISHER, S.S. 1955. Compartive agricultural potentials of the world's regions. Economic Geography 31:82-86.

WALKER, A. 1978. Simulation of the persistence of eight soilapplied herbicides. Weed Research 18:305-313.

WAUCHOPE, R.D. 1978. The pesticide content of surface water draining from agricultural fields $-\mathrm{A}$ review. Journal of Environmental Quality 7:459-472.

WEED, D.A.J., KANWAR, R.S., STOLTENBERG, D.E., and PFEIFFER, R.L. 1995. Dissipation and distribution of herbicides in the soil profile. Journal of Environmental Quality 24:68-79.

WU, L., SWAN, J.B., ALLMARAS, R.R., and LOGSDON, S.D. 1995. Tillage and traffic influences water and solute transport in corn-soybean systems. Soil Science Society of America Journal 59:185-191.

ZHANG, M., and SPARROW, S.D. 2004. Impact of tillage, straw management, and nitrogen fertilizer rate on barley yield and soil properties in a 21-year tillage study in subarctic Alaska. Soil Science Society of America Annual Meeting Abstracts, 31 October - 4 November 2004, Seattle, Washington. Madison, Wisconsin: Soil Science Society of America. (Available on CDROM.) 